\title{
KELIMPAHAN POPULASI, PREFERENSI DAN KARAKTER KEBUGARAN MENOCHILUS SEXMACULATUS (COLEOPTERA: COCCINELLIDAE) PREDATOR KUTUDAUN PADA PERTANAMAN CABAI
}

\author{
Novri Nelly \\ Jurusan Hama dan Penyakit Tumbuhan, Fakultas Pertanian, Universitas Andalas \\ Kampus Unand Limau Manis Padang 25163 \\ E-mail: novrinelly@yahoo.com
}

\begin{abstract}
Population abundance, preference and fitness of Menochilus sexmaculatus (Coleoptera: Coccinellidae) as predator of Aphids in chili plants. This predator is efective to control population of aphids, so the aim of research was to study the field population abundance, predator preference to this prey, and fitness character of $M$. sexmaculatus as predator. The population fluctuation was observed at conventional and organic farming. The preference test was conducted by choice and no choice test for some types of prey. Fitness test was performed by studying its prey, the number of eggs produced and number of eggs hatched. The results showed that M. sexmaculatus population abundance was fluctuated, the abundance higher in chili cultivated conventionaly than cultivated in organic farming. But in conventional farming decreased with increasing age of chili. Preference test showed that almost all species of aphids preferred by M. sexmaculatus. Some prey species found were aphids, thrips and Neotoxoptera. Predator fitness levels showed by the longevity of females ranged 9-10 days. Oviposition period was on average five days, while the post-oviposition was two days. The number of eggs produced ranged $100-200$ eggs with an average of 135.3 eggs.
\end{abstract}

Key words: chili, Coccinellidae predator, population, preference, fitness

\begin{abstract}
ABSTRAK
Kelimpahan populasi, preferensi dan karakter kebugaran Menochilus sexmaculatus (Coleoptera: Coccinellidae) predator kutudaun pada tanaman cabai. Predator ini sangat efektif sebagai pengendali populasi kutudaun. Penelitian ini mempelajari kelimpahan populasi di lapangan, preferensi terhadap beberapa mangsa, dan karakter kebugaran M. sexmaculatus. Fluktuasi populasi diamati pada pertanaman cabai konvensional dan organik. Uji preferensi dilakukan dengan pilihan dan tanpa pilihan terhadap mangsa. Tingkat kebugaran diamati dari jumlah telur yang dihasilkan dan yang menetas. Hasil penelitian memperlihatkan bahwa populasi M. sexmaculatus berfluktuasi. Kelimpahan populasi lebih tinggi pada pertanaman konvensional dibandingkan organik, akan tetapi pada konvensional kelimpahan menurun seiring dengan peningkatan umur tanaman cabai. Uji preferensi mempelihatkan bahwa semua mangsa disukai oleh $M$. sexmaculatus seperti kutudaun, Thrips dan Neotoxoptera. Tingkat kebugaran predator dilihat dari lama hidup betina yaitu 9-10 hari. Masa oviposisi rata rata 5 hari, pasca oviposisi 2 hari. Jumlah telur yang dihasilkan berkisar 100-200 butir dengan rata rata 135,3 butir.
\end{abstract}

Kata kunci: cabai, Coccinellid predator, populasi, preferensi, kebugaran

\section{PENDAHULUAN}

Menochilis sexmaculatus (Coleoptera: Coccinellidae) adalah salah satu agen pengendali hayati untuk hama kutudaun pada tanaman cabai. Predator ini dijumpai di pertanaman dataran rendah sampai tinggi (0-1200 mdpl). Anggota Coccinelidae lainnya yang bersifat predator kutudaun adalah Scymnus fuscan, Scymnus rufel, Verania aflicta, Synonycha grandis, Coelophora inaegualis, Anesolemnia dilatata,
Harmonia sedecimotata, Cheilomenes sexmaculatus, Menochilus sexmaculatus (Amir, 2002).

Hasil penelitian Nelly et al. (2008) menunjukkan bahwa kumbang $M$. sexmaculatus yang diberi pakan kutudaun dari tanaman cabai atau kubis dapat berkembang dengan baik. Demikian juga, predator ini mampu memangsa pada stadia larva dan imago, baik jantan atau betina.

Di Amerika Serikat predator ini sudah digunakan sebagai pengendali hama terutama pada tanaman yang 
ada di taman. Kumbang Coccinellid predator, terdiri atas beberapa spesies yang pada umumnya memangsa serangga serangga kecil (Mathew, 2005). Hasil penelitian Yang (2006) juga menunjukkan bahwa kumbang Coccinellidae Curinus coeruleus (Mulsant) dapat digunakan sebagai agen pengendali hayati kutudaun pada kelapa. Kumbang ini dapat memangsa lebih dari $70 \%$ telur yang diberikan di laboratorium. Nyaanga et al. (2012) melaporkan bahwa jenis mangsa akan mempengaruhi perkembangan dan reproduksi Coccinelid predator.

Keberadaan predator $M$. sexmaculatus ini di lapangan diduga sangat berfluktuasi dan dipengaruhi oleh banyak aspek. Menurut Landis et al. (2000), populasi hama dan musuh alaminya dipengaruhi oleh ekosistem pertanian yang mengalami gangguan setiap musim tanam. Aktifitas budidaya, pembajakan, penanaman dan pemupukan serta panen yang intensif dapat menimbulkan kerusakan pada ekosistem pertanian. Sistem yang terganggu sangat berat memperlihatkan kekayaan spesies yang rendah dan rantai makanan yang pendek, sehingga sedikit spesies yang dapat beradaptasi dengan baik dan berpengaruh terhadap kemelimpahan suatu spesies, terutama musuh alami. Tingkat penggunaan insektisida yang intensif juga sangat mempengaruhi keberadaan hama dan musuh alami di lapangan.

Aspek biologi, perilaku dan ekologi dari hama dan musuh alami perlu dipahami di dalam penerapan strategi pengendalian hayati. Untuk mengembangkan konservasi dan peningkatan kinerja musuh alami, diperlukan pemahaman yang holistic tentang faktor-faktor yang berpengaruh terhadap populasi dan kemampuan musuh alami untuk mengendalikan hama. Dengan kata lain, faktor pembatas bagi peningkatan populasi musuh alami harus bisa diidentifikasi sehingga bisa dilakukan manipulasi untuk meningkatkan populasi alami atau memfasilitasi interaksi antara musuh alami dan hama (Untung, 2006).

Masih banyak informasi lebih lanjut yang dibutuhkan tentang predator ini, seperti kelimpahan populasi di lapangan, preferensi, keperidian dan tingkat kebugaran. Untuk itu penelitian ini bertujuan mempelajari kelimpahan populasi di lapangan, preferensi atau kesukaan pemangsaan predator terhadap beberapa jenis mangsa, serta mengetahui karakter kebugaran $M$. Sexmaculatus. Hal ini perlu sebagai informasi tentang potensinya untuk pengendalian hayati kutudaun pada tanaman cabai.

\section{METODE PENELITIAN}

Waktu dan lokasi pengambilan sampel $M$. sexmaculatus. Penelitian dan pengambilan sampel dilakukan di dua lokasi, yaitu pertanian cabai organik dan konvensional di Kabupaten Lima Puluh Kota Sumatera Barat. Pemeliharaan predator dilakukan di Laboratorium Bioekologi Predator dan Parasitoid Jurusan Hama Penyakit Tumbuhan Fakultas Pertanian Universitas Andalas. Penelitian dilakukan pada bulan Februari sampai November 2009.

Studi Fluktuasi dan Kelimpahan Populasi. Kelimpahan populasi $M$. sexmaculatus diamati pada pertanaman cabai organik dan non organik atau konvensional di Desa Sungai Kamuyang, Kecamatan Luak Kabupaten Limapuluh Kota. Pengambilan sampel dilakukan dengan cara membuat garis transek sepanjang pertanaman yang ada $(1 \mathrm{~km})$ pada masing-masing lokasi dengan pertanaman organik dan konvensional. Jarak antara titik sampel dalam garis transek $100 \mathrm{~m}$. Titik sampel adalah suatu petakan di pertanaman cabai yang berukuran $1 \times 1$ meter, yang diambil secara diagonal dari setiap lahan. Penghitungan populasi pada tanaman cabai secara langsung dilakukan dengan bantuan hand counter. Baik imago maupun larva, semua dihitung sebagai satu populasi predator.

Pemeliharaan Predator dan Kutudaun. Kumbang predator M. sexmaculatus dan hama kutudaun dikoleksi dari pertanaman cabai yang disampel. M. sexmaculatus berupa imago dan larva yang diperoleh di lapangan dibawa ke laboratorium untuk dipelihara dan dibiakkan. Imago dan larva dipelihara pada tanaman cabai yang sudah disiapkan dalam polibag, yang diletakan dalam kurungan berukuran $50 \times 5 \times 50 \mathrm{~cm}^{3}$. Sebagai pakan $M$. sexmaculatus dimasukkan kutudaun dengan perbandingan 1:50, yaitu 1 kumbang M. sexmaculatus diberi 50 kutudaun, setiap 24 jam. Kelompok telur yang dihasilkan imago betina $M$. sexmaculatus diambil setiap hari, dan dipelihara secara terpisah dalam kotak pemeliharaan berukuran $35 \times 27 \times 7 \mathrm{~cm}$. Setelah menetas dan menjadi larva predator dipindahkan ke tanaman cabai yang sudah disiapkan dan dipelihara sampai menjadi imago hingga siap untuk diperlakukan.

Uji Preferensi $M$. sexmaculatus sebagai Predator pada Beberapa Jenis Kutudaun. Pengujian preferensi $M$. sexmaculatus terhadap beberapa jenis kutudaun dilakukan di Laboratorium. M. sexmaculatus dan kutudaun dikumpulkan dari lapangan, dibawa ke 
laboratorium menggunakan kotak berukuran 35 x 27x $7 \mathrm{~cm}^{3}$. Di laboratorium Coccinelid dan kutudaun dipelihara pada tanaman cabai yang ditempatkan dalam kurungan berukuran $50 \times 50 \times 60 \mathrm{~cm}^{3}$.

Uji preferensi dilakukan dengan dua metode yaitu dengan pilihan dan tanpa pilihan. (1) Uji tanpa pilihan (no choice test); yaitu tiga jenis kutudaun (kutudaun dari tanaman cabai, kutudaun tanaman jagung, dan Thrips sp. dari tanaman cabai), masing masing sebanyak 20 ekor kutudaun dipaparkan kepada 1 ekor imago $M$. sexmaculatus selama 30 menit. Kemudian dihitung jumlah kutudaun yang dimangsa, yaitu dengan mengurangi jumlah kutudaun yang dipaparkan dengan jumlah yang masih tersisa. Setiap perlakuan diulang sebanyak 5 kali. (2) Uji dengan pilihan (choice test); satu ekor M. sexmaculatus dimasukkan ke dalam cawan petri kemudian dipaparkan sebanyak masing masing 10 ekor kutudaun dari tanaman cabai, tanaman jagung dan trips dari cabai. Setelah 30 menit dan dihitung jumlah masing-masing kutudaun yang dimangsa predator dengan menghitung jumlah mangsa yang tersisa.

Karakter Kebugaran (fitness) M. sexmaculatus. Imago M. sexmaculatus yang baru muncul dari pupa pemeliharaan, selanjutnya diuji tingkat kebugarannya dengan memberi pakan kutudaun. Satu pasang imago yang baru muncul dimasukkan kedalam kurungan berbentuk tabung (tinggi $25 \mathrm{~cm}$ dan diameter $12 \mathrm{~cm}$ ) dan permukaan atas tabung ditutup dengan kain kasa. Dalam kurungan ditempatkan satu tanaman cabai dengan kutudaun sebanyak 100 ekor sebagai pakan $M$. sexmaculatus. Setiap hari pakan ditambah, dan diamati jumlah telur yang dihasilkan oleh imago betina. Telur dikeluarkan dan dipelihara sampai menetas dalam kotak pemeliharaan (ukuran $12 \times 10 \times 5 \mathrm{~cm}^{3}$ ). Percobaan diulang sebanyak 10 kali. Pemeliharaan imago betina dilakukan sampai serangga tersebut mati. Peubah yang diamati adalah sifat-sifat kebugaran, yaitu: (1) kemampuan memangsa selama 24 jam, (2) lama perkembangan dan lama hidup, (3) masa peletakan telur, dan (4) jumlah telur yang diletakan dan yang menetas.

\section{Analisis Kemampuan Reproduksi (Reproductive} Potential) M. Sexmaculatus. Imago betina $M$. sexmaculatus yang baru muncul dibiarkan berkopulasi, selanjutnya dipelihara dalam kurungan serangga berukuran tinggi $25 \mathrm{~cm}$ dan diameter $12 \mathrm{~cm}$. Pakan berupa kutudaun diberikan setiap hari dengan cara meletakkannya pada tanaman cabai. Setiap hari mangsa ditambah dan imago betina dipelihara hingga bertelur dan sampai berhenti (mati). Pengamatan dilakukan terhadap jumlah telur yang diletakan (potential release).
Analisis Data. Data dianalisis dengan analysis of variance (ANOVA) untuk membandingkan preferensi kumbang terhadap tiga jenis kutudaun sebagai mangsa. Analysis ini dilakukan untuk kedua jenis metode. ANOVA dilakukan dengan menggunakan program STATISTIX 8.0 (Analytical Software for Windows, 2003).

\section{HASIL DAN PEMBAHASAN}

Fluktuasi dan Kelimpahan Populasi $M$. sexmaculatus pada Pertanaman Cabai. Predator yang menyerang kutudaun pada tanaman cabai dan diidentifikasi sebagai Menochilus sexmaculatus. Kumbang ini tergolong ke dalam phylum Arthopoda, kelas Insekta, subkelas Endopterygota, ordo Coleoptera Famili Coccinellidae (Amir, 2002). Panjang tubuh predator berkisar 3,00-3,50 mm, dan kepala berukuran kecil dan tersembunyi di bawah pronotum, yang berwana kuning tua dengan dua pita hitam melintang ke arah sisi elytra. Elytra berwarna kuning dengan pita hitam, dibelakangnya ada pita hitam bengkok serta sebuah totol hitam kecil di posterior elytra (Gambar 1).

Predator ini hampir selalu ditemukan pada pertanaman yang berasosiasi dengan kutudaun, seperti pada pertanaman cabai atau tanaman lain. Kepadatan populasi $M$. sexmaculatus dan kutudaun pada lahan cabai konvensional terlihat sangat berfluktuasi (Gambar 2). Populasi kutudaun sangat tinggi jika dibandingkan dengan populasi $M$. sexmaculatus sebagai predator. Pada pertanaman cabai konvensional, kemungkinan migrasi predator sering terjadi. Hal ini adalah akibat perlakuan insektisida oleh petani.

Jika dilihat berdasarkan waktu atau umur tanaman, kelimpahan populasi lebih tinggi pada awal penanaman.Di awal penanaman penyemprotan insektisida belum dilakukan oleh petani. Selanjutnya kelimpahan populasi predator lebih rendah dibandingkan dengan populasi kutudaun.

Pada lahan organik dapat dilihat bahwa kutudaun ditemukan pada setiap pengamatan. Akan tetapi populasi pada awal pengamatan lebih rendah dibandingkan dengan populasi pada pertanaman cabai konvensional. Kelimpahan kutudaun terlihat berfluktuasi selama pengamatan. M. sexmaculatus belum ditemukan pada pertanaman cabai oganik selama lima minggu pertama pengamatan. Populasi terlihat pada minggu ke enam dan meningkat setelah minggu ke tujuh (Gambar.2). Rata rata populasi tertinggi selama pengamatan adalah 1,5 ekor/rumpun. Gejala serangan kutudaun pada tanaman cabai sangat jelas terlihat pada suatu hamparan pertanaman cabai. Gejala daun yang mengerut dan pada 
daun yang lain akan memperlihatkan gejala menguning (Gambar 4).

Pertumbuhan populasi kutudaun cenderung mengikuti pertumbuhan dan perkembangan tanaman. Terjadinya peningkatan populasi kutudaun pada tanaman cabai yang telah berumur beberapa minggu, disebabkan karena semakin banyak pucuk daun muda yang menjadi makanannya (Muis et al. 1992). Menurut Dixon (2000), pertumbuhan dan reproduksi kutudaun bergantung pada tingkat pertumbuhan tanaman dan kadar nitrogen terlarut di dalamnya. Kadar nitrogen pada daun-daun muda yang sedang tumbuh sangat tinggi, sehingga sangat sesuai bagi kutudaun. Pada daun yang sudah berkembang penuh, cairan floemnya mengandung zat gizi yang rendah bagi kutudaun. Hal ini disebabkan oleh kadar nitrogen yang terlarut di dalamnya relatif rendah.
Fase pertumbuhan atau umur tanaman berpengaruh terhadap perkembangan populasi kutudaun. Populasi kutudaun terus meningkat sampai fase generatif, kemudian populasinya cenderung menurun. Hal ini disebabkan karena tanaman muda dapat menyediakan nutrisi yang lebih baik. Sebaliknya semakin tua tanaman, kualitas nutrisi yang dikandungnya semakin menurun akibat meningkatnya umur tanaman. Pada tanaman sakit atau pertumbuhannya tidak normal, populasi kutudaun relatif rendah, karena kualitas nutrisinya kurang baik.

Dixon (2000) melaporkan bahwa pertumbuhan kumbang predator juga dipengaruhi oleh keberadaan mangsa dan temperatur atau suhu. Suhu yang baik untuk perkembangan dan pertumbuhan kumbang predator M.sexmaculatus adalah $25-30^{\circ} \mathrm{C}$. Jika suhu baik, tanaman (pakan) mangsa cocok, mangsa pun tersedia
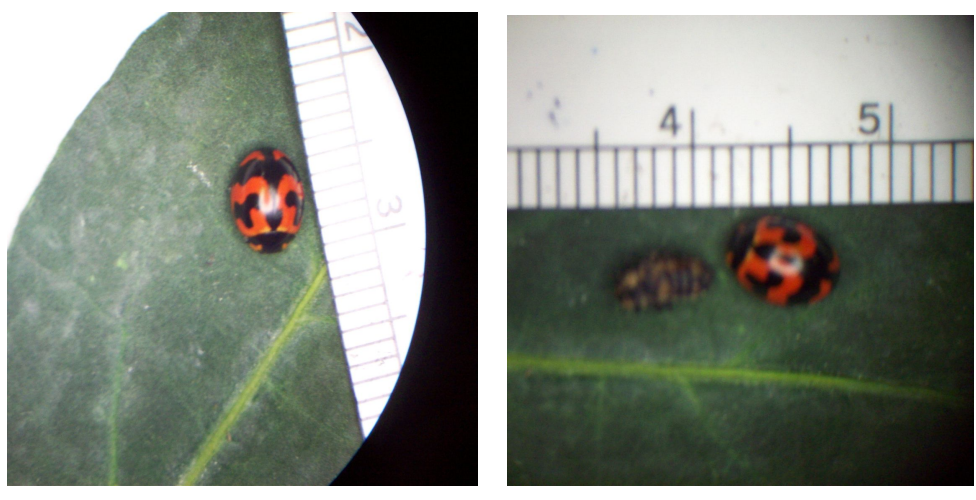

Gambar 1. Imago dan larva M. sexmaculatus predator kutudaun.

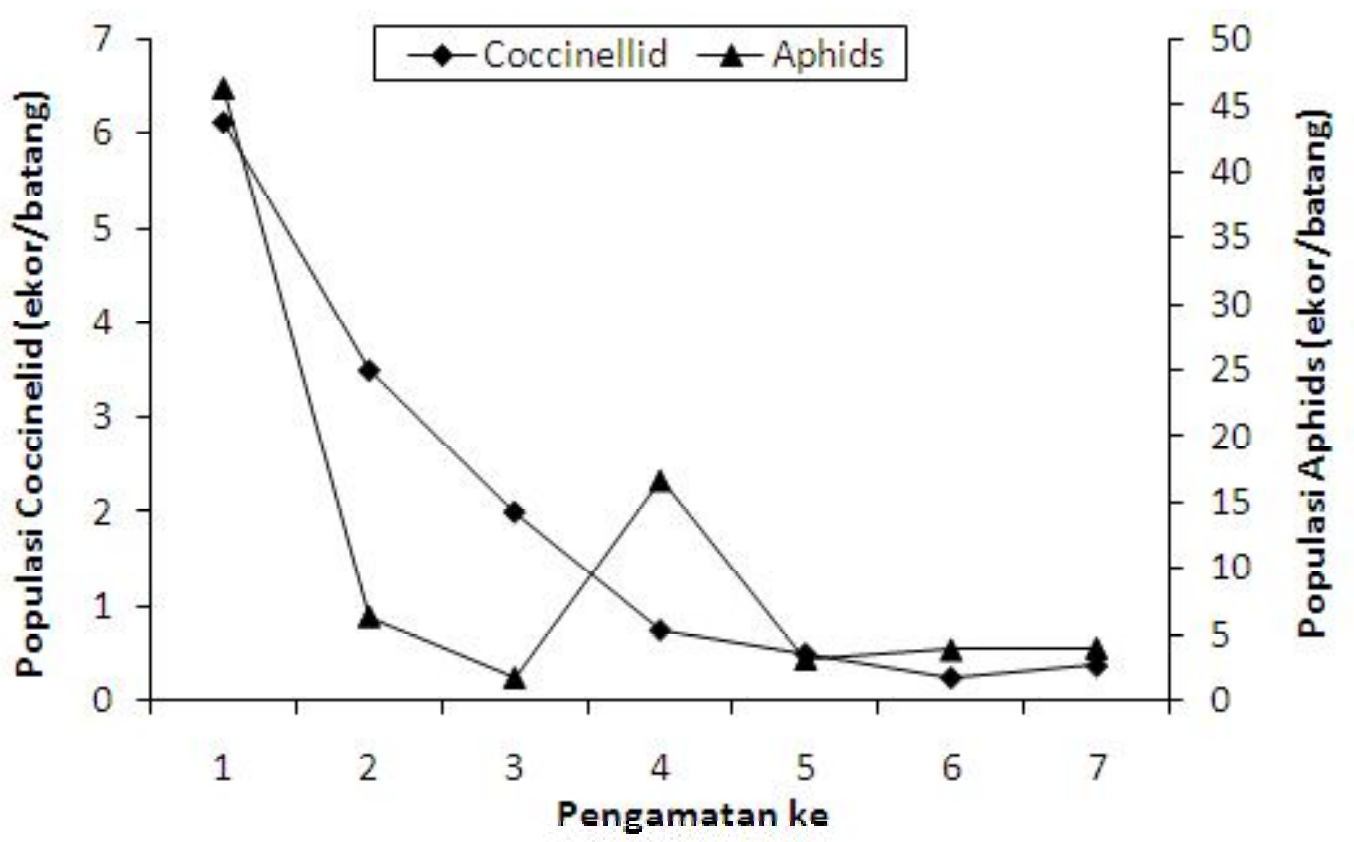

Gambar 2. Fluktuasi populasi populasi M. sexmaculatus dan Aphids sp pada tanaman cabai di lahan konvensional. 


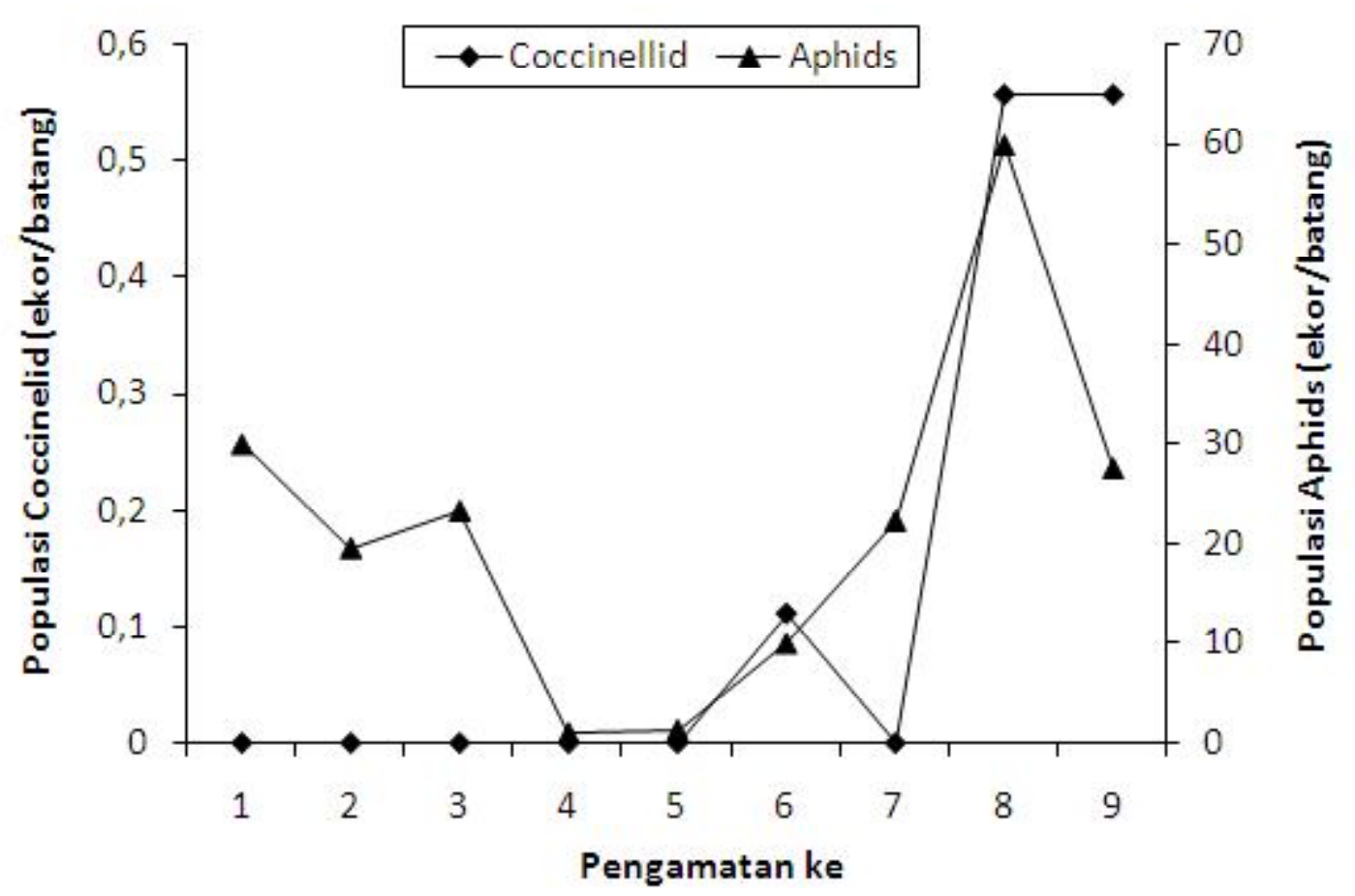

Gambar 3. Fluktuasi populasi Coccinellid dan kutudaun pada pertanaman cabai di lahan organik.
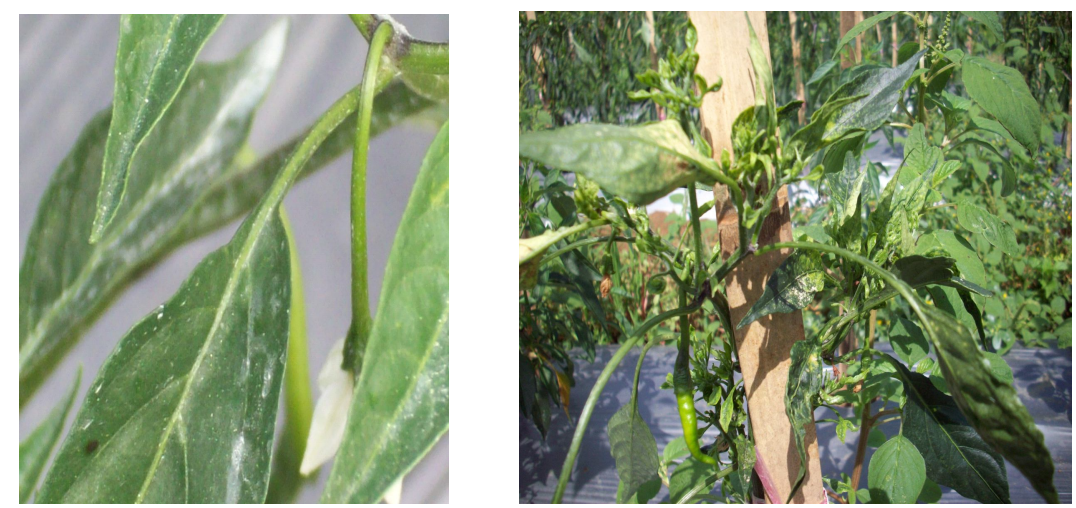

Gambar 4. Gejala serangan kutudaun pada tanaman cabai.

maka pertumbuhan dan perkembangan kumbang predator akan baik pula.

Uji preferensi (prey preference) M. sexmaculatus sebagai predator pada beberapa jenis mangsa. Hasil pengamatan pemangsaan predator Coccinellid terhadap 3 jenis kutudaun yang diberikan secara bersamaan (choice) memperlihatkan persentase pemangsaan yang berbeda. Predator ini menyukai semua jenis kutudaun sebagai mangsa. Uji preferensi predator terhadap kutudaun asal cabai, jagung dan bawang daun memperlihatkan bahwa pemangsaan yang tertinggi adalah terhadap kutudaun tanaman cabai yaitu 92\%, diikuti kutudaun tanaman jagung (79\%). Hasil analisis menunjukkan bahwa persentase pemangsaan tidak berbeda nyata antara mangsa dengan kutudaun asal cabai dan jagung. Demikian juga dengan pemangsaan terhadap kutudaun dari bawang yaitu, $64 \%$ tidak berbeda nyata dengan kutudaun dari jagung, akan tetapi berbeda dengan cabai (Gambar 5). Dapat dikatakan bahwa predator ini menyukai semua kutudaun yang terdapat pada beberapa jenis tanaman. Menurut Hemptinne \& Dixon (1997), dan Mari et al. (2005), kutudaun merupakan mangsa Coccinelid predator, dan Aphis sp. adalah yang utama.

Uji preferensi juga dilakukan terhadap imago $M$. sexmaculatus yang diberi 3 jenis mangsa tanpa pilihan (no choice) memperlihatkan bahwa predator ini juga akan memangsa semua jenis mangsa yang diberikan. Pemangsaan tanpa pilihan memperlihatkan bahwa pemangsaan tertinggi pada kutudaun tanaman cabai 
dibandingkan trips yang juga berasal dari tanaman cabai serta kutudaun jagung (Gambar 6).

Hasil pengamatan daya mangsa imago jantan, betina dan larva memperlihatkan bahwa daya mangsa tertinggi oleh larva dan tidak berbeda nyata dengan imago betina (Gambar 7). Larva mengkonsumsi mangsa selama masa pertumbuhannya, pada umumnya daya konsumsi akan meningkat dengan meningkatnya

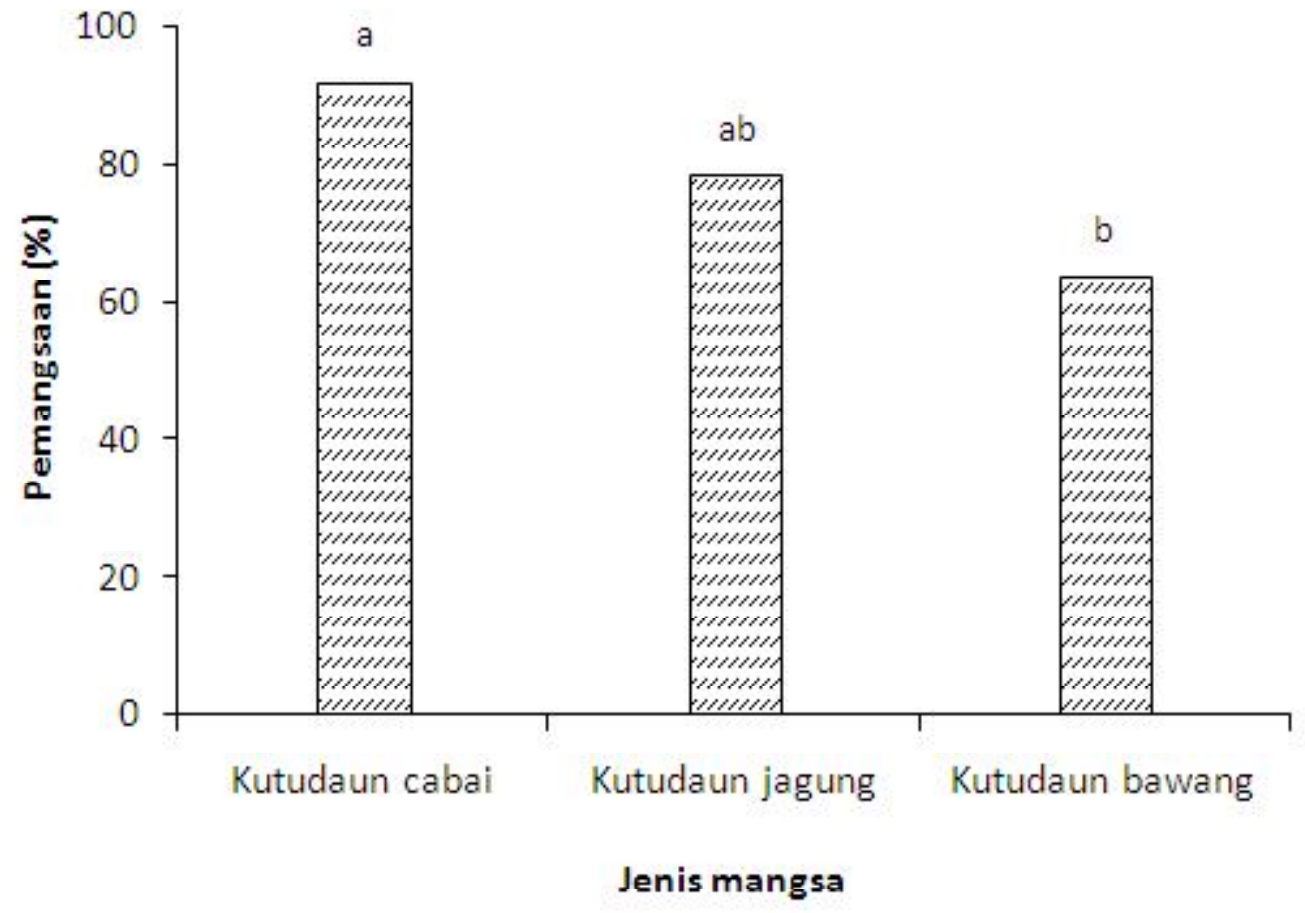

Gambar 5. Preferensi M. sexamaculatus dengan beberapa pilihan jenis. Huruf yang sama di atas bar menunjukkan tidak berbeda nyata menurut uji BNT ( $p>0,05)$.

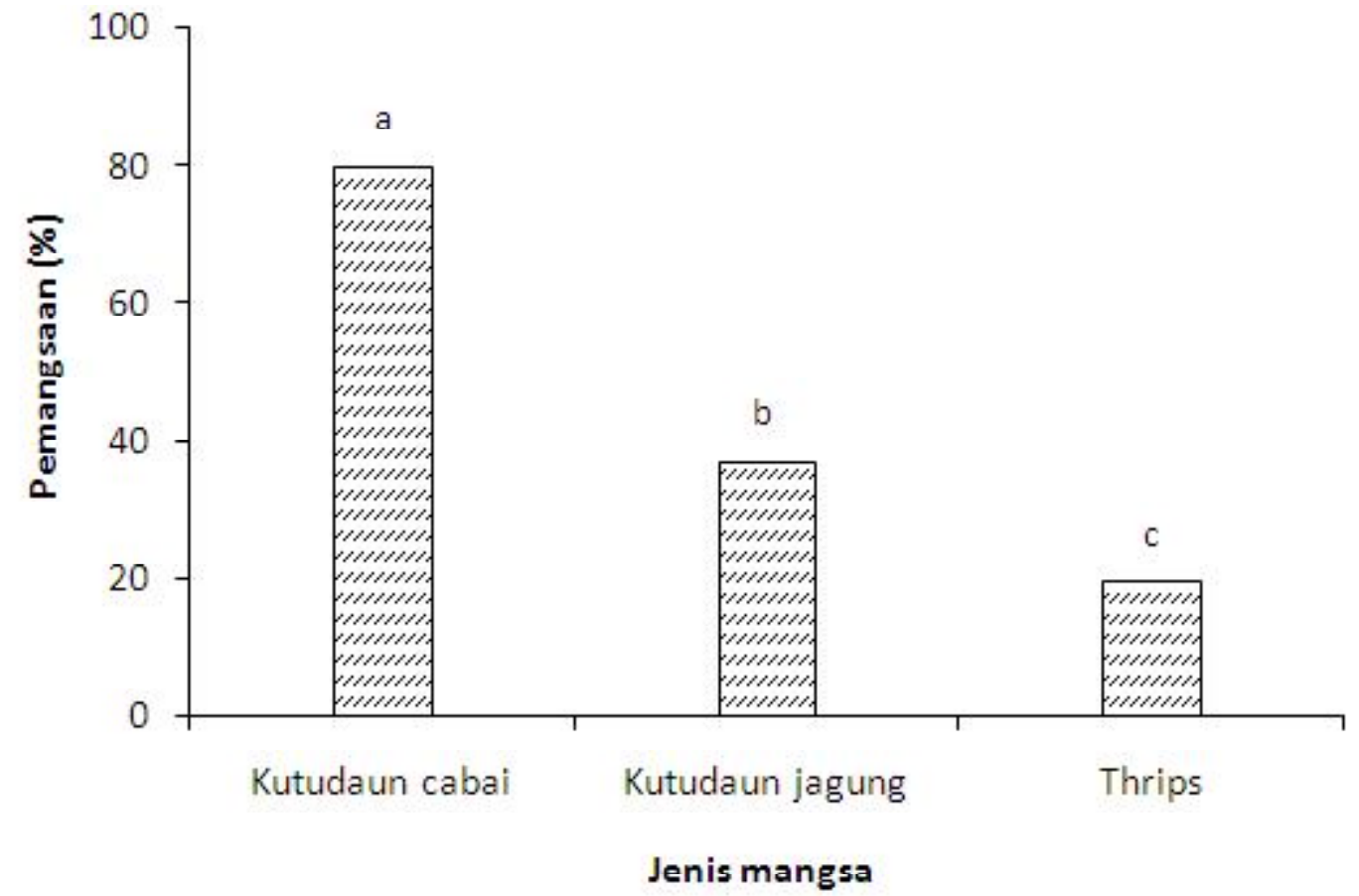

Gambar 6. Pemangsaan M. sexmaculatus pada uji tanpa pilihan mangsa. Huruf yang sama di atas bar menunjukkan tidak berbeda nyata menurut uji BNT ( $p>0,05)$. 
kerapatan mangsa. (Jervis \& Kidd, 1996, Heit et al. 2008). Menurut Frazer (1988), larva instar 4 Coccinellidae lebih efektif dari imago betina dan jantan. Daya mangsa oleh imago betina lebih tinggi dibandingkan imago jantan, diduga karena kebutuhan energi imago betina lebih besar dibandingkan imago jantan.

\section{Karakter Kebugaran (fitness) dan Kemampuan Peproduksi (Reproductive Potential) $M$.} sexmaculatus. Hasil pengamatan terhadap sifat kebugaran $M$. sexmaculatus yang diberi pakan berbeda tidak memperlihatkan perbedaan. Rata rata daya mangsa M. sexmaculatus terhadap kutudaun adalah 70 sampai 80 ekor/24 jam pada tanaman cabai dan jagung (Gambar 8). Masa oviposisi $M$. sexmaculatus yang diberi pakan kutudaun asal cabai dan jagung adalah masing masing 7 hari. Jumlah telur terbanyak yang diletakkan adalah pada hari pertama. Setelah itu menurun sampai masa pasca oviposisi dan mati. Imago tidak lagi meletakkan telur setelah hari ke tujuh. Lama hidup imago betina berkisar antara 9-15 hari. Hasil penelitian Pervez et al. (2004), dan Omkar et al. $(2005,2006)$ menunjukkan bahwa terjadi penurunan jumlah telur yang diletakkan oleh predator dengan bertambahnya umur betina.

Jumlah telur yang dihasilkan imago betina 100200 butir/betina, dengan rata rata 135,3 butir. Hasil pengamatan menunjukkan bahwa $M$. sexmaculatus yang dipelihara dengan pakan kutudaun dari tanaman cabai menghasilkan lebih banyak telur dibandingkan dengan yang diberi pakan kutudaun dari jagung. Jumlah telur yang menetas rata rata lebih dari 50\% (Gambar 9). Hasil pengamatan Bind (2007) terhadap Cheilomenes sexmaculata (Coleoptera:Coccinellidae) menunjukkan bahwa rata rata jumlah telur yang menetas sampai $64 \%$.

Setelah masa oviposisi imago tidak langsung mati tetapi mengalami masa pasca oviposisi. Pada masa ini imago tidak meletakkan telur lagi tetapi masih bertahan hidup dan masih mengkonsumsi Aphis sp sebagai mangsanya. Pada pengamatan masa pasca oviposisi 2 hari setelah terakhir meletakkan telur, ditemukan imago betina yang telah mati. Menurut Dixon (2000), ketahan hidup predator bergantung pada kualitas makanan, tanaman inang dan suhu lingkungannya.

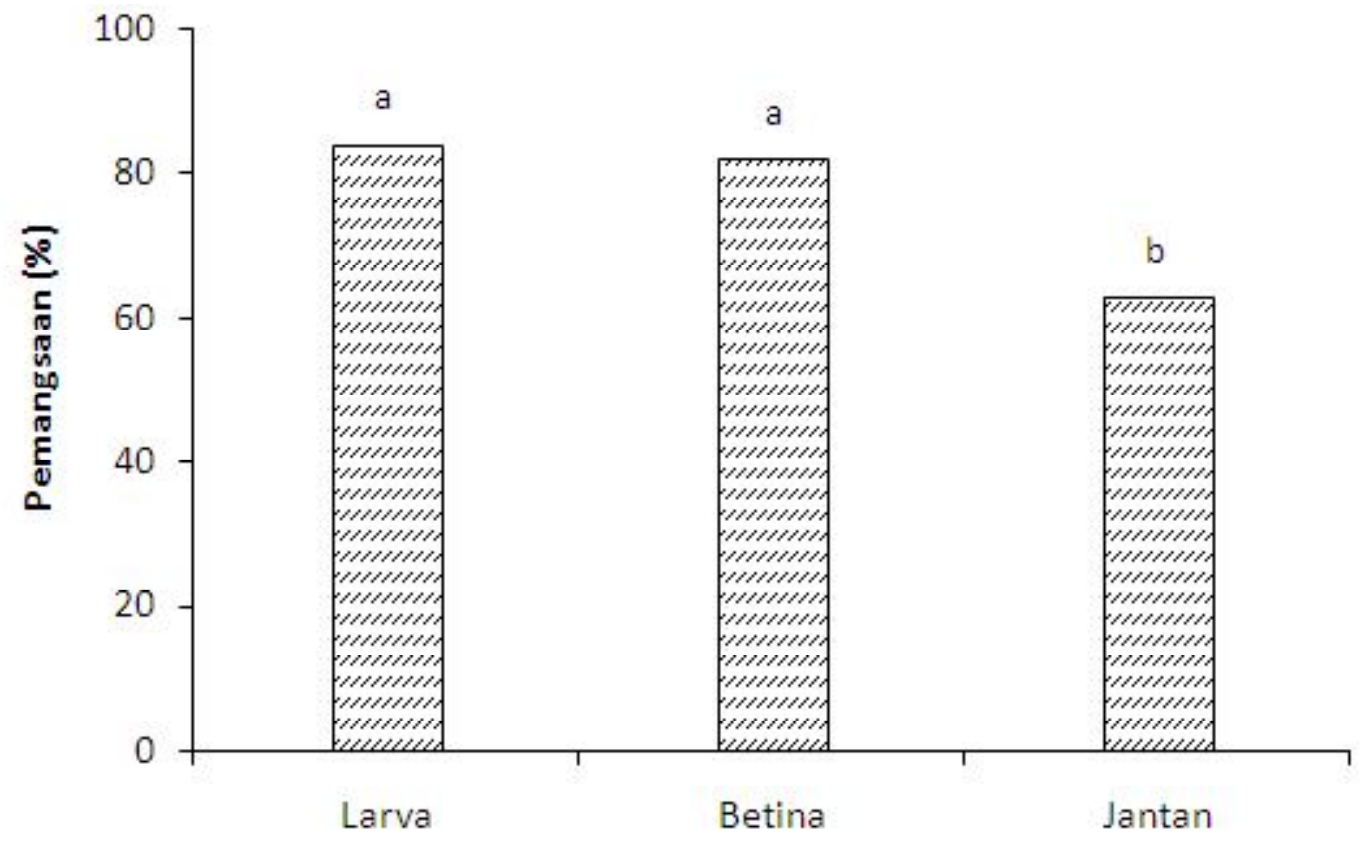

\section{Coccinellid}

Gambar 7. Daya mangsa $M$ sexmaculatus larva, jantan dan betina. Huruf yang sama di atas bar menunjukkan tidak berbeda nyata menurut uji BNT (p>0,05). 


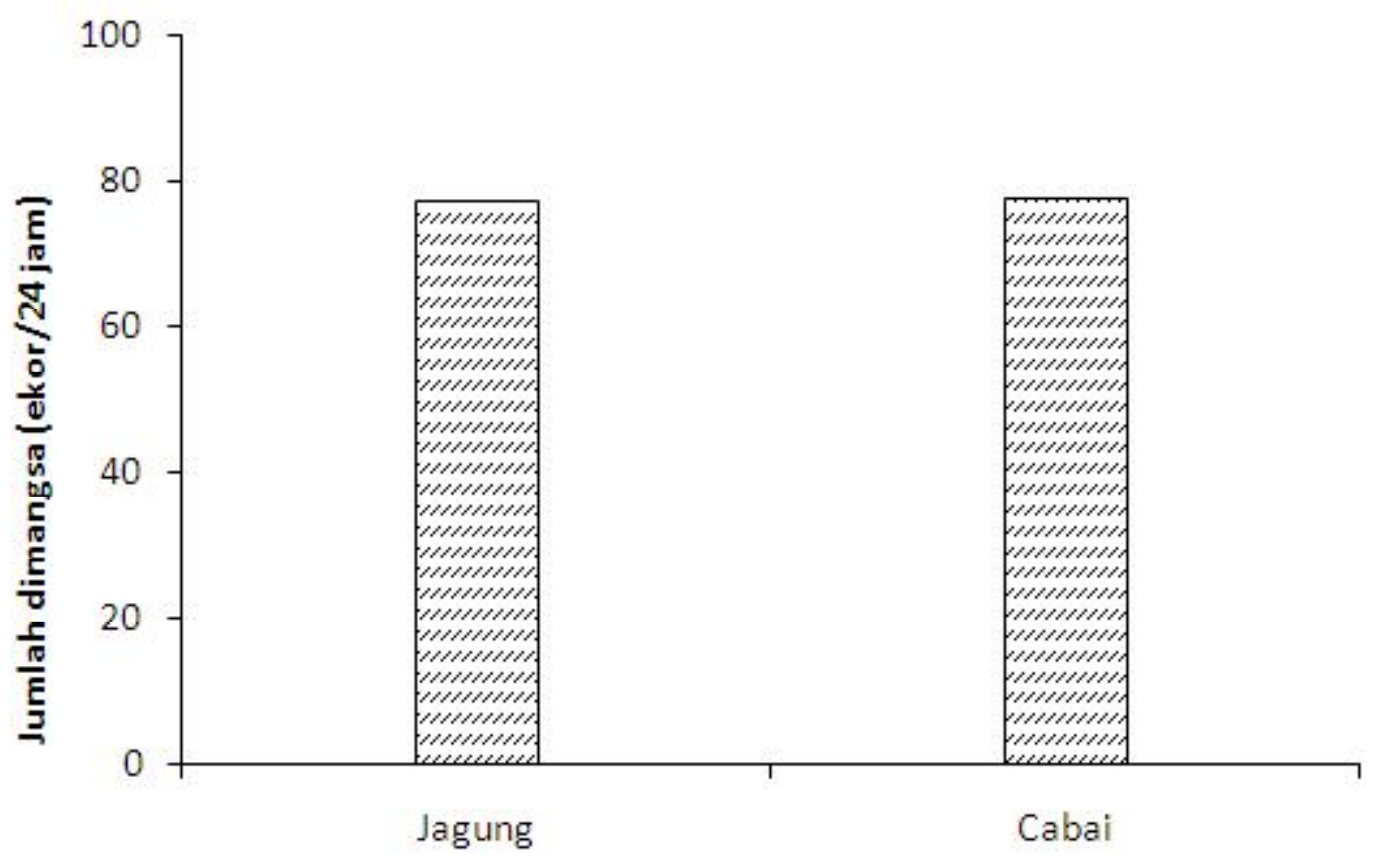

Tanaman asal kutudaun

Gambar 8. Daya mangsa predator terhadap kutudaun yang berasal dari tanaman jagung dan cabai (ekor/24 jam).

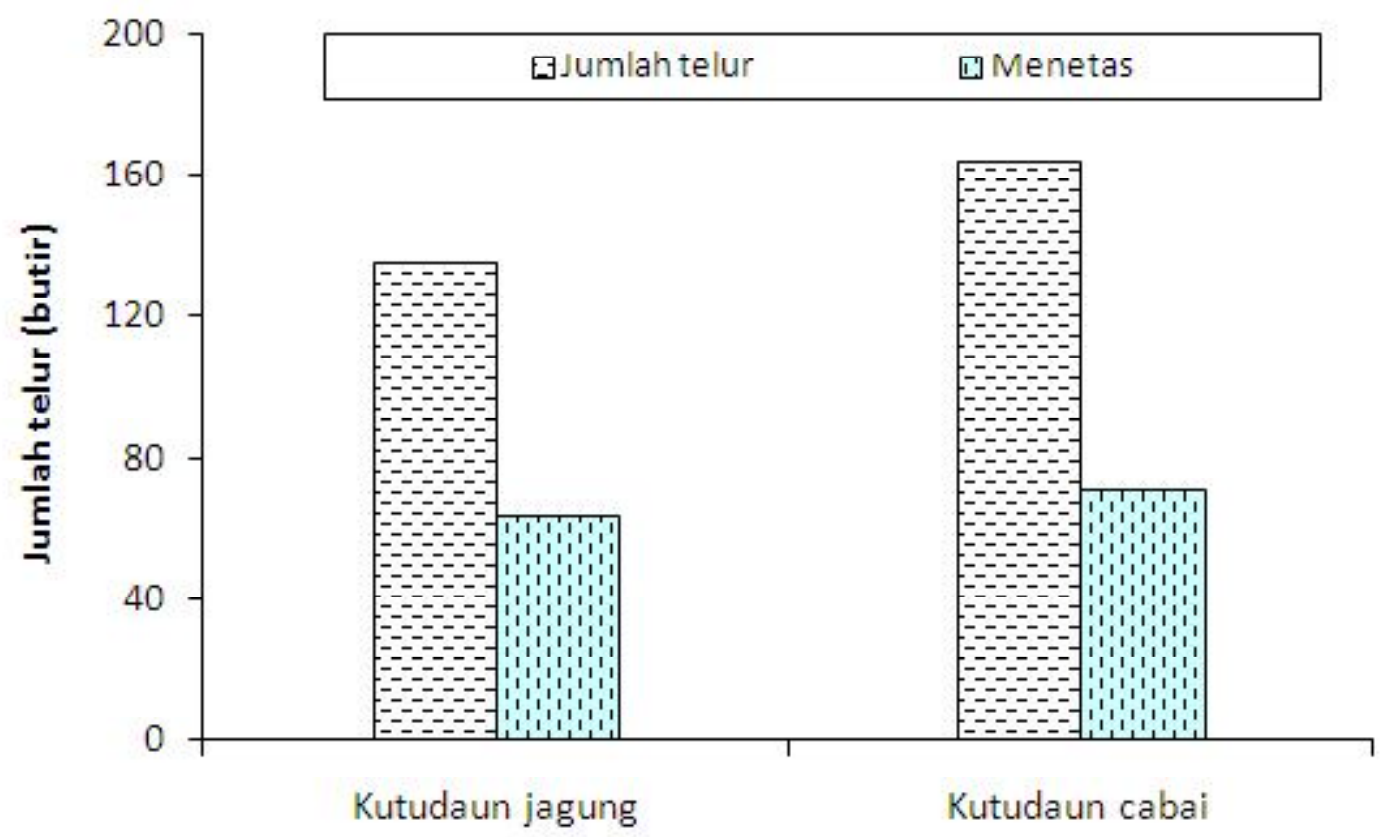

Jenis mangsa

Gambar 9. Jumlah telur yang dihasilkan dan menetas oleh betina M. sexmaculatus dengan mangsa berbeda. 


\section{SIMPULAN}

Hasil penelitian menunjukkan bahwa populasi $M$. sexmaculatus berfluktuasi, kelimpahannya pada cabai konvensional lebih besar dibandingkan pada pertanian cabai organik. Akan tetapi pada pertanian konvensional kepadatan menurun dengan bertambahnya umur tanaman cabai. Preferensi $M$. sexmaculatus menunjukkan bahwa hampir semua jenis kutudaun disukai predator ini. Kebugaran M. sexmaculatus dapat dilihat dari lama masa hidup betina yang berkisar antara 9 -15 hari. Masa oviposisi adalah rata rata 7 hari, dan masa pasca oviposisi 2 hari. Jumlah telur yang dihasilkan satu betina berkisar 100 -200 butir dengan rata rata 135,3 butir.

\section{SANWACANA}

Ucapan terima kasih dan penghargaan disampaikan kepada Bapak Aldafrizal dan Morlewi $\mathrm{H}$ yang telah membantu penyiapan tanaman serta serangga uji di lapang dan laboratorium.

\section{DAFTAR PUSTAKA}

Amir M. 2002. Kumbang Lembing Pemangsa Coccinellidae Di Indonesia. Bogor. Biodiversity conservation Project.

Bind RB. 2007. Reproductive behaviour of a generalist aphidophagous ladybird beetle Cheilomenes sexmaculata (Coleoptera: Coccinellidae). International Journal of Tropical Insect Science 27: 78-84.

Dixon AFG. 2000. Insect Prey Predator Dynamics Ladybird Beetles and Biological Control. New York : Cambridge University press.

Frazer BD. 1988. Aphids Their Biology.Dalam Minks AK \& Harrewijn P. (Eds) Natural Enemies and Control Volume B. Elsevier. Amsterdam-oxfordsNewyork-Tokyo. 235-237.

Heit G, Cohen G \& Mareggiani G. 2008. Impact of odor signals on Cycloneda sanguinea (Coleoptera: Coccinellidae) searching behavior. Cien. Inv. Agr. 35(2):205-210.
Hemptinne, JL \& Dixon AFG 1997. Are Aphidophagous Ladybirds (Coccinellidae) Prudent Predators?. Entomological Research in Organic Agriculture 151-159.

Jervis M \& Kidd N. 1996 Insect Natural Enemies.Practical Approaches to their study and evaluation. Chapman and Hall. London.Weinhelm- New York-Tokyo-Madras.

Mari JH, Rizvi NH, Nizamani SM, Qureshi KH \& Lohar MK. 2005. Predatory Efficiency of Menochilus sexmaculatus Fab. and Coccinella undecimpunctata Lin., (Coccinellidae: Coleoptera) on Alfalfa Aphid, Therioaphis trifolii (Monell.). Asian Journal of Plant Sciences 4: 365-369.

Matthew P. 2005.Top Tech City: Minneapolis, MN, PopSci.com (http://www. popsci.com/scitech/ article/2005-03/top-tech-city-minneapolismn?page=4). Diakses pada 19 April 2008.

Muis A, Haswanuddin A, Surapati U \& Fachruddin. 1992. Intensitas serangan Pstv dan fluktuasi populasi Aphis craccivora serta predatornya pada empat waktu tanam. J. Agrikam. 15 (1). 17-23.

Nelly N, Usra S \& Arman D, 2008. Daya predasi kumbang Coccinellid predator hama kutudaun tanaman cabai. Laporan Penelitian Jurusan HPT Faperta Unand Padang.

Nyaanga JG, Kamau AW, Pathak RS \& Tuey RK, 2012. The Effect of Different Cereal Aphid Species on the Performance of Two Coccinellid Predators. Journal of Entomology 9: 41-49.

Omkar, Mishra G, Srivastava S, Gupta AK \& Singh SK. 2005. Reproductive performance of four aphidophagous ladybirds on cowpea aphid, Aphis craccivora Koch. J. Appl. Entomol. 129(4):217220.

Omkar, Singh SK \& Singh K. 2006. Effect of age on reproductive attributes of an aphidophagous ladybird, Cheilomenes sexmaculata. J. Insect Science 13(4): 301-38,

Pervez A, Omkar \& Richmond AS, 2004. The influence of age on reproductive performance of the predatory ladybird beetle. Propylea dissecta. J Insect Sci. 4: 22-25. 
Untung K. 2006. Pengantar Pengelolaan Hama Terpadu. Gadjah Mada University Press. Jogjakarta.
Yang P. 2006. Laboratory study of predation Curinus coeruleus (Mulsant) (Col;Coccinellidae) on eggs of Aedes albopictus (Diptera:Cullcidae). J.Proc. Hawaian Entomol.Soc. 38 (127-129). 